\title{
ECCLESIASTES \\ AND THE END OF WISDOM
}

\author{
Martin A. Shields
}

\begin{abstract}
Summary
Many readers of Ecclesiastes have contrived to discover orthodox meaning for the words of Qohelet. An examination of two such readings reveals the shortcomings of both and paves the way for an alternative understanding of the book. Close analysis of the epilogue reveals that, although partially favourable towards Qohelet himself, the epilogist is unequivocally critical of the sages as a group. It appears that the epilogist may thus have employed Qohelet's words in order to reveal the failure of the sages and warn their prospective students to adhere to the commands of God. The book of Ecclesiastes thus functions as a tract designed to discredit the wisdom movement, using the sage Qohelet's own words in order to do so.
\end{abstract}

\section{Introduction}

Readers of the Old Testament have long struggled to impose upon Qohelet's unorthodox and troubling conclusions some degree of palatable orthodoxy. ${ }^{1}$ Historically the dominant approach has been to propose interpretations which ultimately see in Qohelet's words the teaching of thoroughly orthodox ideas, albeit through rather unorthodox means. I shall begin this article with an examination of two such interpretations of Ecclesiastes and highlight some significant problems inherent in any approach which attempts to impose orthodoxy on the words of Qohelet.

\footnotetext{
1 For clarity I shall adopt the convention employed by Andrew Shead in using 'Ecclesiastes' to refer to the biblical book in its entirety, and 'Qohelet' to refer to the character whose voice we hear through Ec. 1:2-12:7. See A.G. Shead, 'Ecclesiastes from the outside in', Reformed Theological Review 55.1 (1996), 2437.
} 
In direct contrast to these interpretive strategies has been a growing trend to revel in Qohelet's unorthodox teachings. James Crenshaw has recently given voice to this trend, writing that 'to regard Qoheleth as a teacher of quietude, simplicity, enjoyment, the limits of vice and virtue, fear of God, and carpe diem is to rob his words of their exceptional power'. ${ }^{2}$ However, such an understanding of Qohelet itself fails to account for the presence of Ecclesiastes amongst the canonical books of the Old Testament. The bulk of this article is given over to providing an interpretive strategy which fully exploits the troubling nature of Qohelet's words whilst accounting for their presence within the Old Testament.

\section{Ecclesiastes: The view from below}

One of the most common approaches to interpreting Ecclesiastes, both historically and amongst some scholars today, establishes a distinction in Qohelet's thought between his analysis of life 'under the sun' or 'under heaven'- that is, without reference to God-and the life of faith in God. The former is shown to be meaningless, whilst the latter provides meaning and fulfilment in life. In doing this, it is claimed, Qohelet's aim is to direct his audience away from self-dependence and toward faith and trust in God. ${ }^{3}$ Michael Eaton's own summary of the purpose of Ecclesiastes is representative:

What, then, is the purpose of Ecclesiastes? It is an essay in apologetics. It defends the life of faith in a generous God by pointing to the grimness of the alternative. $^{4}$

The problem with this interpretation, however, is that Qohelet never uses the meaninglessness of existence 'under the sun' as a basis for

2 J.L. Crenshaw, 'Character in crisis', Interpretation 51.4 (1997), 424.

3 Some examples of this type of understanding of Ecclesiastes include M.A. Eaton, Ecclesiastes (TOTC; Leicester: IVP, 1983); G.S. Hendry, 'Ecclesiastes' in F. Davidson (ed.), The New Bible Commentary (London: IVP, 1953); D. Kidner, $A$ Time to Mourn and a Time to Dance (Leicester: IVP, 1976); L. Ryken in L. Ryken \& T. Longman III (ed.), A Complete Literary Guide to the Bible (Grand Rapids: Zondervan, 1993), 268-80. Eaton, 37-38, notes that 'Christian orthodoxy has generally held that [Qohelet's] purpose was to lift the heart to heavenly things by showing the futility of the world. This was the view of many Reformers and Puritans and their successors (Whitaker, Pemble, Cocceius, the "Dutch Annotations", John Trapp, Matthew Poole, Matthew Henry).'

4 Eaton, Ecclesiastes, 44. See also Roland E. Murphy, Ecclesiastes (WBC 23A; Dallas: Word, 1992), xlviii-lvi, who offers a summary of the history of interpretation of Ecclesiastes. 
arguing for 'the life of faith'. Whilst it is true that Qohelet presupposes the existence of an omnipotent, sovereign God, it is clear that he also believes that God's actions and purposes are mysterious. Qohelet believes that we cannot know why God does what he does, and so the only perspective presented by Qohelet is that from 'under the sun'. Qohelet claims no access to any other perspective. It is only the interpreters of the work who have supplied such a perspective in order to provide an acceptable interpretation of Qohelet's remarks. ${ }^{5}$ The claim that Qohelet examines the consequences of secular thinking and shows their bankruptcy in order to show that the only viable worldview is a theistic one framed by fear of God and obedience to his commands, fails because Qohelet himself never makes the final connection. It may be true that Qohelet's words demonstrate the bankruptcy of a secular world-view, but Qohelet himself never progresses beyond discovering that bankruptcy, except to conclude that the best we can do is to make the most of the situation in which we find ourselves.

It is, of course, easy to discount such interpretations without closely examining the case their proponents would set forth. These scholars appeal to the passages in Ecclesiastes which speak of God's work in order to substantiate their claim that Qohelet is indeed putting forward both alternatives-life without God versus a life of faith in God. Eaton explains this quite clearly:

For much of the time the argument leaves God out of account. Then dramatically the Preacher introduces God and all changes. The 'under the sun' terminology falls into the background or lapses altogether $(2: 24-26$; $11: 1-12: 14)$; instead he refers to the 'hand of God' (2:24), the joy of man $(2: 25 ; 3: 12 ; 5: 18,20 ; 9: 7 ; 11: 7-9)$, and the generosity of God $(2: 26 ; 3: 13$; 5:19). Ecclesiastes is thus an exploration of the barrenness of life without a practical faith in God. Intermingled with its pessimism are invitations to a different outlook altogether, in which joy and purpose are found when God is seen to be 'there' and to be characterized supremely by generosity. 6

However, a closer examination of the passages which supposedly argue for the life of faith shows that they do not prove as much as is claimed. This can be demonstrated by considering the first of the passages listed by Eaton (Ec. 2:24-26):

5 This approach is by no means new, see Svend Holm-Nielsen, 'On the interpretation of Qoheleth in early Christianity', VT 24 (1974), 175. Graeme Goldsworthy, Gospel \& Wisdom (Exeter: Paternoster, 1987), 108-109, also briefly discusses some of these interpretations.

6 Eaton, Ecclesiastes, 45. 
There is nothing better for mortals than to eat and drink, and find enjoyment in their toil. This also, I saw, is from the hand of God; for apart from him who can eat or who can have enjoyment? For to the one who pleases him God gives wisdom and knowledge and joy; but to the sinner he gives the work of gathering and heaping, only to give to one who pleases God. This also is vanity and a chasing after wind. [NRSV]

Reading this passage it is difficult to be quite as positive as Eaton about Qohelet's 'different outlook'. The rhetoric is hardly positiveQohelet does not declare this conclusion to be a good thing, he only says that there is nothing better for us. Contra Eaton, Qohelet certainly cannot perceive any 'purpose' in what comes to us from God. Reading Qohelet's words here prompts us to ask ourselves if there really is nothing better for us than to 'eat, drink, and find enjoyment in our toil'? Is there no more to life than this? Even from within the perspective of the Old Testament this conclusion is difficult to warrant. Indeed, in Ecclesiastes 3:16-22 Qohelet again concludes that there is nothing better for us than to enjoy our work, but this time because he has observed that death, in which we suffer the same fate as animals, is the great equaliser- 'for the fate of humans and the fate of animals is the same; as one dies, so dies the other. They all have the same breath, and humans have no advantage over the animals; for all is vanity' (Ec. 3:19, NRSV). Bill Dumbrell correctly summarised Qohelet's thought in this passage thus: 'This fact [that death brings all human endeavours to nought] forces us to the conclusion that we must live for the moment, accepting what God, this somewhat remote figure, gives, since nothing can be done apart from him and since he disposes as he pleases. ${ }^{7}$

Another problem with Eaton's approach is that the context of this passage suggests that for Qohelet, the one who 'pleases' God here is not necessarily one Qohelet deems worthy. That this is so can be seen by comparing verse 19 , where the one who stands to inherit the fruits of Qohelet's labours may well be foolish, with verse 26, which tells us that the 'sinner' is the one who labours so that the one whom God finds 'pleasing' will receive the fruits of that labour. ${ }^{8}$ For Qohelet, there is no way to determine whom God finds pleasing or displeasing - God's choice appears arbitrary.

7 William J. Dumbrell, The Faith of Israel (Leicester: Apollos, 1988), 242-43.

8 M.V. Fox, Qohelet and His Contradictions (JSOTS 71; Sheffield: Almond Press, 1989), 188-89. Fox notes that v. 19 implies that the recipient may be a fool, whilst v. 21 implies that the unfortunate man may toil in wisdom. See also Murphy, Ecclesiastes, 26-27. 
Finally, Qohelet closes the section declaring this too to be 'vanity and a chasing after wind'. Whilst there is much debate over the precise significance of the term 'vanity' (הָרבל) in Ecclesiastes, there is agreement that it has negative overtones. Furthermore, a good case can be made for interpreting Qohelet's דֶֶ declarations as expressions of his inability to find any reasonable explanation for the events and circumstances he has set out to understand. Whether this is the meaning of in Ecclesiastes or not, that it is a clearly negative statement indicates that if Qohelet is really trying to establish that the life of faith is the only escape from the meaninglessness of existence without God in these verses, then it is inappropriate for him to conclude that this too is 'vanity and a chasing after wind'.

In light of these considerations it is apparent that the approach of the many interpreters of Ecclesiastes who manage to read this (and similar passages elsewhere) as arguing for a life of faith and obedience faces insurmountable obstacles. When we read these passages without the premature compulsion to force them somehow to fit into the perspective of the remainder of the canon, it becomes clear that the substance of Qohelet's argument is that because God's ways are impenetrable to us, we ought to make the most of whatever situation we find ourselves in.

\section{Ecclesiastes from the outside in}

Scholars are increasingly acknowledging that the epilogue to Ecclesiastes plays a decisive role in arriving at an interpretation of the work which is sensitive to the book's place within the canon. Ignoring the epilogue to Ecclesiastes would be akin to ignoring God's appearance at the end of the book of Job. In that book, God appears and declares that Job's friends were mistaken in the arguments they presented. In Ecclesiastes, the epilogist tells us as readers how we ought to understand the words of Qohelet which we have been reading.

A.G. Shead has recently argued that Qohelet's message is summarised by the statement made in the epilogue, 'fear God and keep his commandments'. Although Shead is correct in looking to the

9 Shead, Reformed Theological Review 55.1. On p. 27 Shead writes, '...we believe a more natural reading reveals a narrator whose conclusions not only fail to contradict Qohelet, but actually claim to distil his words in summary'. Shead has built upon his earlier arguments in 'Reading Ecclesiastes "epilogically"', TynB 48.1 (1997), 67-91. Cf. also Eaton, Ecclesiastes, 152, 156. 
epilogue for answers about the purpose of the book, his interpretation of the epilogue, and so of the entire book, presents some problems. My aim here is to critique this conclusion on methodological grounds, and subsequently to provide an alternative interpretation of the epilogue and consequently of the function of the book of Ecclesiastes.

Shead adopts a form of structuralist approach to interpreting the book of Ecclesiastes, arguing for a specific meaning of the epilogue (and consequently of the words of Qohelet to which the epilogue refers) based upon lexical links both within it and beyond it to the body of the work. The question raised by his use of this approach is whether the underlying structure controls the meaning or whether that structure enhances the meaning of the work conveyed through the surface level of the text. Shead basically argues that the structure of Ecclesiastes indicates that the teaching of Qohelet is summarised in the epilogue, specifically in the words 'fear God and keep his commandments' found in Ecclesiastes 12:13. Reading Shead's justification for this view leaves the impression that some amount of exegetical legerdemain has been exercised in arriving at this conclusion. Shead himself concedes that his conclusion cannot be derived from a simple reading of the work when he writes:

This is such a surprise to the average first-time reader of the book that it is tempting to consider the epilogue a re-interpretation, an imposition of more orthodox thought on an unsettling work. However the structural features just discussed do not suggest that this is the case, and neither does the most natural exegesis of the epilogue lend itself to such a position. ${ }^{10}$

Shead's structural approach to interpreting the epilogue may be illustrated by considering his analysis of the word דָָָ ('word, matter, thing'). He explains,

More than anything else in the first half of the epilogue, Qohelet's wisdom is described as one of 'words'. It is therefore highly significant that the narrator should choose to use רָּר in vs. 13 (literally, 'the end of the word; the all is heard'). Like so much of his thought, this points in two directions, the general and the specific. On a general level, vs. 13 gives the reader 'the final word', namely, the statement about fearing God. But specifically, it is a pointed reference back to the 'words' of Qohelet (and other sages) which tell

10 Shead, Reformed Theological Review 55.1, 31. Shead goes on to say on p. 35 that 'the sticking point with many scholars is the apparent lack of support for the sentiments of 12:13f. in the body of Ecclesiastes, and so claims are made that in $12: 13$ the epilogist is "putting forward an ideal which has been developed elsewhere and which is not a concern of Ecclesiastes"'. 
us that when Qohelet has had his say, it all amounts to 'fear God and keep his commands'. 11

Shead suggests that the repeated use of and keep his commandments' in verse 13 is a summary of Qohelet's teaching. However, רָדָ is one of the more common words in Biblical Hebrew, and it is certainly not uncommon in Ecclesiastes. It is necessary to ask whether the repetition of this term is sufficient to encourage the reader to see the links suggested by Shead. Moreover, if דָּבָר in verse 13 is a 'pointed reference' back to the words of Qohelet and other sages, should we not then conclude that verse 13 is providing a summary of all such words? Yet to claim that the words of Qohelet and other sages can be summarised by the statement 'fear God and keep his commandments' is surely rather presumptuous.

Furthermore, the argument presented by Shead relies on a great deal of inference for which there is inadequate substantiation within the text. For example, if the use of the word דָָָ in verse 13 is intended to function as a link back to the use of the term in verses 10 and 11, why can it not be understood as providing the last word which effectively puts an end to all the words of the sages? It is not enough to establish the presence of a verbal link within the text, it is necessary to establish the significance of that link. Even if we were to grant that the repeated

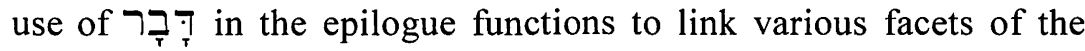
argument, it is not clear that this linkage determines that the epilogue is providing a summary of the words of Qohelet. It may be providing an answer not found in the words of the sages. The danger inherent in much structural analysis of the sort in which Shead engages is that the structure may ultimately support more than one possible interpretation. Close exegesis of the text is necessary to determine how the structure

11 Shead, Reformed Theological Review 55.1, 30. This style of argument is used extensively by Shead. Another example can be found in his comments on 12:10: "The prominent link with "a time" (ע) or with God's judgment in 4 of the 6 occurrences outside 12:10 suggests that reality of judgment and so able to enjoy life's delights despite the appearance of vanity. This suggests that דברי חפיץ are words that give delight to life because they reveal the existence of God's justice and of a (resultant?) time for all good things' (A.G. Shead, Ecclesiastes 12:9-14: Reading the Epilogue as an Epilogue [M.Th.; Australian College of Theology, 1995], 49). Surely the absence of the term עִ here would suggest that if we are going to look at other passages in Ecclesiastes to determine the meaning here we ought to look at those passages where חקטכ occurs without עِת. 
is to be understood, and we shall see below that such exegesis does not support Shead's conclusions. ${ }^{12}$

Another example of the difficulty of sustaining this argument can be seen in Shead's attempt to link the two synonyms for 'end' (YP in v. 12; סוֹ in v. 13), and from this link to argue that "an "end" of the limitless task described in the proverb of vs. 12 is finally being announced'. ${ }^{13}$ Surely, however, if the author of the epilogue wanted unequivocally to establish such a link the repetition of the same word would have been clearer than the use of a different term. That is, after all, the way Shead argues that the epilogist has worked elsewhere.

Finally, despite the verbal links Shead discovers between the epilogue and the words of Qohelet which precede it, it is difficult to see how Ecclesiastes 12:13 can actually summarise Qohelet's words. Qohelet has nowhere made reference to the law or the prophets. Indeed, his argument has systematically ignored any revelation by God to his people in which he might have found answers to the questions he pondered. The exhortation to 'fear God and keep his commandments' stands at odds with Qohelet's conclusions. ${ }^{14}$

These considerations leave Shead's approach to the epilogue-and so to the interpretation of the book of Ecclesiastes-somewhat wanting. There is clearly a danger in reading too much into verbal links within a text and determining meaning primarily from the structure of the narrative. It will become clear in the next section that the statement of verse 13 of the epilogue does not summarise Qohelet's teaching. Whilst Shead is correct in recognising that the words 'fear God and keep his commandments' summarise the message of the book of Ecclesiastes, it is the relationship of these words to the teaching of Qohelet where Shead is on shaky ground.

12 Shead has also made this same error in a more recent article, cf. TynB 48.1 (1997), 70.

13 Shead, Reformed Theological Review 55.1, 30.

14 This conclusion is widely recognised, cf. Crenshaw, who states that 'the attempt to sum up Qoheleth's teaching in 12:13-14 misses the point entirely...Instead, the epilogist offered advice that was intended to replace Qoheleth's counsel' (J.L. Crenshaw, 'The Wisdom Literature' in D.A. Knight and G.M. Tucker (ed.), The Hebrew Bible and Its Modern Interpreters [Philadelphia: Fortress, 1985], 378). Shead's own comment that 'in contrast to (Qohelet's) endless activity, there is something final that can be done: fear God and keep his commands' (TynB 48.1, 69), appears to confirm the disjunction between the epilogist's advice and Qohelet's teaching rather than (as Shead would elsewhere have it) set forth v. 13 as a summary of Qohelet's message. 


\section{Rereading the epilogue}

The words of the epilogist (or, according to a number of scholars, epilogists) to Ecclesiastes have themselves been interpreted in a number of different ways, making it difficult to summarise approaches to them. In general, however, these words are seen as either partly or wholly positive toward Qohelet. For those who understand them to be only partly favourable, then it is usually the first half of the epilogue (vv. 9-11) which is said to speak uncritically of Qohelet, whilst the second half (vv. 12-14) speaks less positively about Qohelet and the wise. This supposed mixing of different attitudes toward Qohelet is principally responsible for the view that the epilogue may have been composed by more than one hand.

In distinction to these views, however, I shall demonstrate that the epilogue in its entirety can be understood to be critical of the wisdom movement. The epilogist has attached his comments to Qohelet's words which, as far as the epilogist is concerned, represent both the pinnacle of the wisdom of that time and the ultimate illustration of the point he wishes to make. These words of Qohelet have been released to the public by the epilogist to highlight the problems he perceives in the wisdom movement. Precisely how this is achieved will be made clear as we examine the epilogue in detail.

\section{A biographical comment}

The epilogue opens by making some specific comments about Qohelet, before moving to address the sages in general. The opening words have posed some difficulty to interpreters, but Seow's solution, understanding the particle $\ddot{i}$ in a causal sense, reflects an occasional usage of this particle in Biblical Hebrew, is supported by the use of ö $\tau$ in the LXX, and overcomes the difficulties associated with alternative explanations. ${ }^{15}$

The use of the term רתי to open the epilogue indicates that the epilogist is providing us with additional information about Qohelet. There are several parts to this information. First, Qohelet was a sage (חָ term ${ }^{2} \prod_{T}$ here does not designate a member of a specific class of wise person within society, there are a number of indications within the epilogue that suggest that the term is, in fact, better understood to refer to a member of an identifiable class of wise people within ancient

15 Choon-Leong Seow, Ecclesiastes (AB; New York: Doubleday, 1997), 383. 
Israelite society. Fox has noted a number of instances where almost certainly refers to a member of a specific group as opposed to any wise person. He also argues that the use of the expression

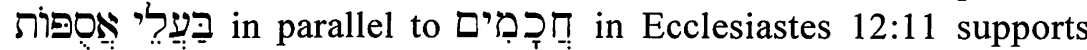
interpreting the latter term as referring to a sage. ${ }^{16} \mathrm{In}$ addition, it is not clear why the epilogist would feel the need to explain that Qohelet was wise-that much has been made apparent by Qohelet's own wordswhereas it would be necessary to identify him explicitly as a member of the community of sages. Indeed, if the epilogist is using חָָ in the broader sense it is difficult to justify the statements made about these people in the following verses. Finally, the causal understanding of the particle שֶ directly associates being a the people knowledge'-a task which would appear to involve a level of commitment above that which would be expected of any person who was wise. The statement is clearly suggestive of a professional position.

Second, he constantly taught knowledge to the people. Grammatically this is set forth as the consequence of being a sage. The fact, however, that the epilogist felt it necessary to state this explicitly suggests that the original audience may not naturally have reached this conclusion. It appears likely that, although the epilogist felt that the job description of the sages ought to have included teaching the public, the sages of Qohelet's day were failing in this aspect of their role. ${ }^{17}$

Third, Qohelet listened to, researched, and corrected the wisdom of others. There has been extensive discussion of the meaning of each of the terms which make up the second half of verse 9. Seow has convincingly argued that 5 should be understood as 'to listen'. ${ }^{18}$ The verb חק חק occurs only here in the piel, but generally means 'investigate, research, discover'.

The final verb in this group of three, context to mean 'to correct'. Gordis and others render this verb by 'composing', but this is based on later usage and overlooks the use of the term elsewhere within Ecclesiastes. When Qohelet uses this term in Ecclesiastes 1:15 and 7:13, he is referring to something which is bent (עות) and cannot be straightened (תקק). The use of this term in

16 Fox, 330-32. See also Seow, 384; Murphy, 125.

17 Seow, 383, appeals to Sir. 37:23 to make the point that there was a widespread expectation that sages should teach the public, and so this cannot be considered special information about Qohelet. A good case can be made, however, that the wisdom movement had undergone some amount of reform by the time of Sirach.

18 Seow, 383; cf. Fox, 323. 


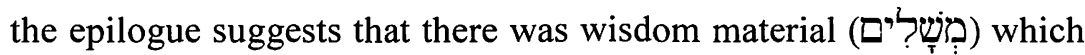
needed to be 'straightened', which was, in some way, 'bent' or not straight. ${ }^{19}$ That Thould be understood to mean 'to correct' is lent further support by the fact that Qohelet's antonym, עות, means 'pervert, corrupt' in the piel or pual. ${ }^{20}$ Thus one of Qohelet's activities was to correct wisdom material which was in some manner corrupted. Qohelet achieved this through listening to the wisdom of others and researching the subject matter for himself. The description of this careful procedure highlights the quality of Qohelet's work-where Qohelet differed in his conclusions from other sages, Qohelet is to be believed because he has studied their material and corrected it.

The importance of this observation cannot be overstated. That Qohelet felt it necessary to correct the wisdom of other sages clearly indicates that there were problems within the wisdom movement. We shall see that the remainder of the epilogue adds further weight to this position.

Fourth, Qohelet preferred to speak truthfully rather than offer

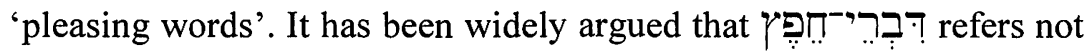
to the meaning of the words, but to their aesthetic qualities. ${ }^{21}$ The usual justification for this explanation lies in the literary nature of wisdom literature, where style was supposedly highly prized. It is also likely that this explanation is adopted because the description 'words of delight' stands quite at odds with the message conveyed by Qohelet's words. ${ }^{22}$

Yet there are good reasons for believing that this expression does indeed refer to the meaning, the content of the words, not just to their aesthetic quality. The epilogist does not claim that Qohelet succeeded in finding 'pleasing words'-only that he sought them. Indeed, it is likely that the epilogist is suggesting that Qohelet did not find such words. In the body of the work, Qohelet records his expectation of

19 The term מִשְׁל should probably not be restricted in reference to the short sayings which make up the bulk of the book of Proverbs. The term is used in the OT to apply to a wide variety of literary forms, cf. Ezk. 17:1-24; Nu. 23:7, 18; Dt. 28:37; Jb. 13:12; 27:1.

20 Seow, 385, notes that in post-biblical Hebrew, range which included the meaning 'to straighten, repair', which is much the same meaning I argue is appropriate in the present context.

21 Gordis, 352; J.L. Crenshaw, Ecclesiastes (OTL; London: SCM, 1988), 191; Whybray, 171; Murphy, 125.

22 Crenshaw, Ecclesiastes, 191, says that 'many readers have not concurred in the statement that Qohelet's observations are both pleasing and trustworthy'. 
finding positive results to his enquiries, only to be frustrated and forced to conclude each investigation with the הבר declaration.

An examination of instances of finite forms of the verb בִ בִ followed by the infinitive reveals that the success or failure of the search is not made apparent simply by the use of these words. ${ }^{23}$ This observation suggests that the expression (finite $ב$ ? construct) establishes the existence of the search but does not predetermine the outcome. In most instances, the success or failure of the search is established subsequently in the narrative.

The use of this expression in the epilogue, however, comes after the record of the words of Qohelet. Both reader and epilogist have the data before them to enable them to determine whether Qohelet was successful in finding 'pleasing words'. The mere fact that the text does not state that Qohelet found 'pleasing words' suggests that the epilogist is insinuating that Qohelet did not succeed, but still wants to make the point that this was Qohelet's original aim. However, it is also unlikely that the epilogist is suggesting that Qohelet was a failure because he did not succeed in finding 'pleasing words'. Rather, the epilogist is asserting that Qohelet's initial aim was to find pleasing answers to the issues he investigated. His lack of success in finding pleasing words indicates not a failure but rather highlights his integrity - instead of falling back on easy and 'pleasing' answers (as perhaps other sages would do, resulting in the need for their work to be corrected), Qohelet preferred to state the truth. This last point is made explicit by the last clause of verse 10 .

The final clause of this verse emphatically states that the words Qohelet wrote were the truth. Whilst the clause contains a number of grammatical problems (the passive participle

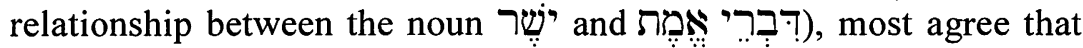
the epilogist is endorsing Qohelet's words. ${ }^{2 \dot{4}}$

Why did the epilogist feel it necessary so to endorse Qohelet's words as truthful? A number of explanations could probably be offered. Qohelet's words have always (so far as we can determine) troubled those who have read them and tried to understand them against the background of the faith of Israel. They do not fit easily with the wisdom of other sages as recorded in Proverbs (or, for that

23 The search is successful in Gn. 43:30; $1 \mathrm{Sa}$. 14:4; $1 \mathrm{Ki} .11: 22 ; \mathrm{Zc} .6: 7 ; 12: 9$, but is not successful in Ex. 2:15; 4:24; Dt. 13:10; 1 Sa. 19:2, 10; 2 Sa. 21:2; $1 \mathrm{Ki}$. $11: 40 ; 19: 10$ and elsewhere.

24 Seow, 385-86, offers a satisfying treatment of these issues. 
matter, from other sources in the Ancient Near East), and the wisdom of Qohelet's contemporaries could probably also be included. Consequently, it would be tempting to dismiss Qohelet's words and adhere to the more traditional conclusions of the sages (which could perhaps best be described as 'pleasing words'). The epilogist here makes clear that the words of Qohelet are true. Where other sages may have offered different advice, they are the ones who should be considered to be incorrect-not Qohelet.

In summary, this biographical information provided by the epilogist reinforces the effect of the implied identification of Qohelet with Solomon in the opening chapters of the book to show that Qohelet was not just one more sage, he was an exceptional sage. He shared the epilogist's belief that the sage ought to share the benefits of their wisdom with the general public. Qohelet was not satisfied with the wisdom of other sages, where truth was apparently compromised in order to provide satisfying answers. Rather, he felt it necessary to correct the wisdom of his fellow sages. The fact that correction was necessary itself suggests that there were problems within the wisdom movement.

\section{Warnings about the teaching of the sages}

Verse 11 marks a shift in focus of the epilogue away from Qohelet and his words in verses 9-10 to the words of the sages in general in verses 11 and 12 (amongst which Qohelet's words are certainly included). Verse 11 takes the form of a wisdom saying regarding the words of the sages. Although the saying has generally been interpreted as extolling the words of the sages (and in many cases is understood to ascribe to them a divine origin), we shall see that the saying is actually somewhat negative about the value of the words of the sages and, given the critical thrust of the remainder of the epilogue, is best understood as a warning.

The saying takes the form of a poetic tricolon, with the first two cola in synonymous parallel. ${ }^{25}$ There is widespread agreement that the first colon likens the words of the wise to the goads used to herd cattle. Furthermore, there is general agreement that this simile is asserting that the words of the wise have the power to direct one's path, to guide one in living a better life. The most uncertain element of the first colon is the identity of the wise, although the use of the parallel term

25 The semantic parallelism is reinforced by the chiastic grammatical parallelism between the first two cola. 


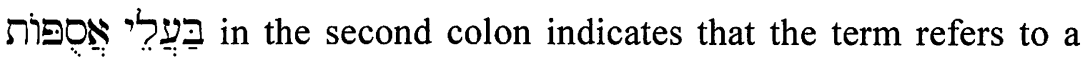
specific class of the wise-the professional sages.

The second colon is not so clear. The precise function of the

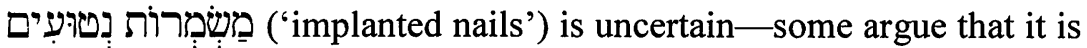
a reference to sharp nails embedded in the ends of wooden stakes to serve as makeshift goads, whilst others understand this to refer to something nailed firmly in place and so immovable. Given the parallelism with the previous colon, together with the general use of pastoral imagery in the first and third cola (cf. the reference to the רنֶֶה 'shepherd'), it is preferable to adopt the former interpretation.

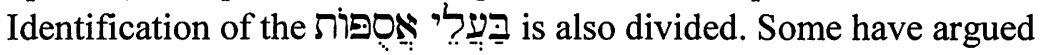
that this is a reference to the individual sayings which make up collections of wisdom material based on instances in Biblical Hebrew where refers to a participant or member of some group. However, wherever בַַּע is used to refer to a participant, or member of a group, it always maintains some notion of mastery or ownership. ${ }^{26}$ In the present context, however, it is difficult to contrive any justification for claiming that an individual saying in a wisdom collection holds any mastery over the entire collection, thus making such an interpretation of the term here improbable. Consequently, it is best to understand

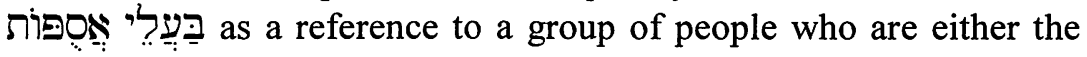
compilers of collections of wisdom sayings or else overseers of gatherings of people (whichever type of collection sִ refers to). In either case, the reference is clearly to a specific group, and the wisdom context of the epilogue as a whole together with the use of $\prod_{T}$ in the first colon indicates that the reference is to a specific group of wise people - that being the sages or professional wise people.

The second colon, then, appears to be likening the sages themselves to implanted nails. Although explanations of the significance of this simile could no doubt be offered, it is perhaps preferable to understand

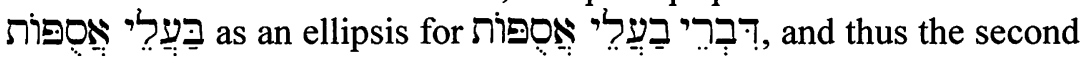
colon reflects closely the meaning of the first, likening the words of the sages to implements used by pastoralists to direct and control their herds. ${ }^{27}$

26 Cf. Fox, 324. For such usages of בַַּ compare Gn. 14:13; Ne. 6:18.

27 Gordis, 353, objects that the passage is insufficiently poetic to employ ellipsis. However, this saying is itself thoroughly poetic-employing parallelism, imagery, paranomasia together with other poetic devices. Furthermore, ellipsis in language (including Biblical Hebrew) is not confined to poetry but is frequently found in quite unpoetic texts. 
The interpretation of the final colon in this saying is critical to understanding the saying as a whole. The crucial element in this colon is the identification of רֶֶֶ been identified as Moses, Solomon, or Qohelet, the vast majority of scholars now identify the shepherd as God. ${ }^{28}$ This conclusion is reached primarily because of the use of the shepherd metaphor elsewhere in the OT with reference to God. The consequences of this identification are that the subject of the verb נִ נת is the words of the wise, and that the words of the wise are thus endowed with divine authority since God is their ultimate source.

In spite of its widespread acceptance, the identification of the shepherd as God faces insurmountable problems. First, if understood as asserting the divine origin and authority of wisdom literature, the saying claims too much. Whilst most who adopt this understanding of the text assert that the epilogist is asserting the inspiration of Qohelet's words, or at most the canonical wisdom literature, there is no indication that the saying is so restrictive. The subject matter is not some of the words of the wise, but rather the words of the wise without qualification. Attempts to restrict the scope of this reference are less than convincing. Furthermore, that Qohelet is said by the epilogist to have corrected the wisdom material of other sages (cf. v. 9) indicates that the epilogist could not have agreed that the words of all of the sages were inspired. Indeed, the negative assessment of the wisdom movement inherent in the epilogue further highlights the inappropriateness of the claim that this text proposes a divine origin for the wisdom of the sages.

Second, the argument that the use of the term רעיע would evoke in the audience an instant connection to God is anachronistic. When the shepherd metaphor is used of God elsewhere in the OT the text makes the identification explicit (such as in 'Yahweh is my shepherd' where the reader is left in no doubt as to the identity of the shepherd). ${ }^{29}$ The absence of any text where the term רֶֶֶה stands unqualified as a

28 Amongst those making such an identification are Gordis, 354; Murphy, 125; G. Ogden, Qoheleth (Sheffield: JSOT Press, 1987), 210. Whybray, 172, is unhappy with the identification of the shepherd as God but feels that no better alternative has been offered. Shead, 1995, 53-55, argues that the reference is to both Solomon and God.

29 OT texts which refer to God metaphorically as a shepherd are Gn. 48:15; 49:24; Pss. 23:1; 28:9; 80:1; Is. 40:11; Je. 31:10; Ezk. 34:12; Mi. 7:14. Shead, 1995, 55, claims that Je. 17:16 refers to God as shepherd of his people. The meaning of that text is problematic, but if read as describing anyone as a shepherd, it is clearly a reference to Jeremiah, not God. 
reference to God makes it unlikely that such an identification should be made here. ${ }^{30}$

Third, the presence of the adjective $7 \Pi$ poses problems for the identification of the shepherd as God. Whybray notes the problem and comments that 'this apparent assertion of the oneness of God also seems to be made with no obvious reason' ${ }^{31}$ Were the epilogist actually interested in identifying the shepherd as the one God (or the God who is one) the point would have been more clearly made had the

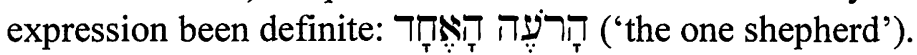

These considerations indicate that the cannot reasonably be identified as God. Furthermore, the expression is clearly too vague to evoke any certain identification with any specific historical figurewhether Moses, Solomon, or Qohelet-besides which it is not at all clear how any such figure could be said to have given either the words of the sages or the goads and implanted nails. Thus we are left to conclude that the reference here is simply to a shepherd, and that the subject of the verb נִ can only be the goads and implanted nails (for it would be ludicrous to suggest that all of the wisdom of the sages originated in the ponderings of itinerant pastoralists formulated while they tended their herds).

Given that רעיעה is not being used in some metaphorical sense, the adjective shepherd as opposed to all other shepherds. Instead, it could be understood as roughly equivalent to the indefinite article in English, so highlighting the fact that the reference here is simply to any ordinary shepherd. ${ }^{32}$ Alternatively, the adjective could be used to highlight the fact that the shepherd here referred to, who must use goads and implanted nails to control a herd, is alone. ${ }^{33}$ This may then make reference to the greater need of a lone shepherd for these implements to overcome the difficulties of handling a herd unaided by other shepherds. Whether this could have been the case, however, must remain uncertain given our lack of knowledge about some aspects of ancient shepherding practices.

We are finally in a position to determine the meaning of this saying which likens the words of the sages to the goads used by shepherds in

30 The only other occurrences of the expression רעשֶה are in Ezk. 34:32 and 37:24 where it represents the Davidic messiah, not God.

31 Whybray, 172.

32 So Seow, 388; Fox, 325-26.

33 The adjective Ki. 19:4; Ezk. 33:24; 1 Ch. 29:1. 
controlling their herds. Seow follows the typical understanding when he explains that 'The words of the wise may hurt; they are not what one may choose to hear. Yet in the end, they are better for one's wellbeing. 34

In spite of the widespread acceptance of this interpretation, the saying is more ambiguous than most acknowledge. If the path set out by the sages is good, then being directed along that path would no doubt also be good. However, this aphorism does not draw any conclusions about the worth of the advice of the sages-it certainly does not conclude that this advice is 'better for one's well-being'. If the path set out by the sages is not good, then this saying must stand as a warning against heeding the wisdom of the sages lest it direct us down that path. The saying says nothing of the value of the advice of the sages, nor of the outcome of following that advice. Instead, it comments upon the manner in which the sages use language. They use it in the same way that a shepherd uses a goad-to manipulate and coerce the hearer to follow their direction. The wisdom of the sages could, according to this saying, be used to manipulate and ultimately lead the student of wisdom astray. Given the negative evaluation of the sages suggested by the need for Qohelet to correct their wisdom (cf. v. 9) and the additional negative statements in the subsequent verse, it is better to read in this saying something of this negativity towards the words of the sages.

The similes chosen by the author of the saying do not depict the wisdom of the sages as working through gentle instruction or parental advice. Rather, the image here is one of coercion, where the sages' words function as harsh and painful means to constrain and manipulate the path of the 'student'. ${ }^{35}$ These harsh terms used to describe the effects of wisdom material upon the student of wisdom also present a sharp contrast to the desirable words Qohelet is said to have sought in the previous verse.

The next verse, verse 12 , is usually taken to begin a new section within the epilogue. This decision is based upon two factors. First, verses 9-11 are generally recognised to speak positively about wisdom and Qohelet, whilst verses 12-14 appear to be somewhat less

\footnotetext{
34 Seow, 393.

35 Longman comments that 'The metaphors of goads and embedded nails, while usually understood positively, are better understood as negative. Goads and nails are painful!' (R.B. Dillard and Tremper Longman III, An Introduction to the Old Testament [Grand Rapids: Zondervan, 1994], 254). Fox also highlights the painful nature of the words of the sages, cf. Fox, 1989, 324-25.
} 
enthusiastic in their approval-warning the reader against the preoccupations of the wisdom movement (i.e. making books and studying excessively), and offering what appears to be an alternative to the life led by the sages-obedience to the Law. Second, the repetition of רִ וִ suggests that something additional is about to be stated.

However, this bipartite division of the epilogue faces some difficulties. First, as I have sought to demonstrate, verses 9-11 are not so positive about wisdom as many would claim. Whilst verses 9-10 speak positively about Qohelet, in doing so they discredit other sages and so the wisdom movement in general. Verse 11 is best read as a warning against the wisdom of the sages. Thus there is no sharp disjunction in attitude toward the sages between the first half and second half of the epilogue. Second, the repetition of the opening word of the epilogue at the beginning of verse 12 appears to function to bind verse 12 to verse 11 -offering an additional warning to that of verse 11. Third, the transition from a focus specifically on Qohelet in verses 9-10 to the sages in general in verses 11-12 forms a strong semantic shift in the epilogue suggesting that a tripartite division (consisting of the three pairs of verses 9-10,11-12, and 13-14) more adequately accounts for the contents of the text than the usual bipartite division. ${ }^{36}$

Verse 12 is clearly a warning, although the nature of the warning is disputed. For those who understand verse 11 to assert the inspiration of wisdom writings (or rather, of certain wisdom writings, in spite of the absence of any indication that the sayings referred to should be constrained in any way), verse 12 is usually understood as a warning against anything beyond that corpus. ${ }^{37}$ However, the problems associated with interpreting verse 11 in this manner make this interpretation untenable. ${ }^{38}$

Part of the difficulty in interpreting the opening clause of verse 12 lies in the clause division suggested by the Masoretic accents. The presence of the athnah under the word רָi indicates that the Masoretes read this word as a part of the first clause of the verse, the second clause therefore beginning with the infinitive construct עַשוֹ.

36 This argument is enhanced by the significant semantic shift from v. 12 to vv. 13 and 14 , where the focus moves away from the wisdom movement altogether.

37 So Crenshaw, Ecclesiastes, 191.

38 Fox adds that if understood as a warning against words other than those of the wise, then 'What would those be-some sort of secular literature? If so, this warning comes entirely without preparation, and the ancient reader, no less than the modern, would need a clearer identification of the words/books of the non-wise. Otherwise how could the reader know what to avoid?' (Fox, 326). 
However, in every other occurrence of an imperative followed immediately by an infinitive construct in Biblical Hebrew the two

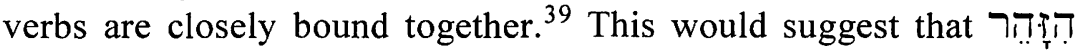
belongs with the second clause rather than the first. This relegates the opening clause to function in a more connective sense, the pronoun referring back to what has already been said in a general sense. ${ }^{40}$ Thus the opening clause merely functions to introduce the warnings of verse 12 as additional pieces of advice to that which has already been written - 'in addition to this, my son...'

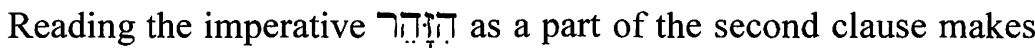
the advice an emphatic warning: 'beware of making books excessively' rather than a mere observation about the activities of the sages. It unambiguously presents a negative assessment of the tasks the sages undertook. Furthermore, it is apparent that the tasks described here-making books and study-must refer to the activities of sages, for they have been the focus of the epilogue from its beginning. To suggest a more general application-as many modern students would feel is appropriate-divorces this text from its context.

Is it reasonable to conclude that the epilogist felt that Qohelet's efforts, along with the other sages, should prompt this warning? It appears likely that Qohelet's words have been recorded, at least in part, to bear out this warning. Qohelet's overriding conclusion was that all was . For every task he set out to understand, he always wound up reaching this same conclusion. In the end, Qohelet has proven the point-there was no end, no goal, only הֶֶ. The task of the sages is an empty and futile task, because the answers they seek are not available to them (cf. Ec. 8:17). The epilogist's earlier exhortation of Qohelet as pre-eminent amongst the sages only serves to demonstrate that where other sages may have claimed to have found an end in their quest they were mistaken (and so were in need of the correction which the epilogist stated that Qohelet provided). Qohelet, the greater sage, had spoken honestly and made it clear that there was no end.

39 This construction appears in only five other places in Biblical Hebrew: Is. 1:16 (perhaps); 23:16; Je. 15:15; 18:20; Ps. 33:3. A more general form of this construction is a finite verb immediately followed by an infinitive construct. This too, frequently binds the two verbs together and invests the infinitive with some adverbial function. See B.K. Waltke and M. O'Connor, An Introduction to Biblical Hebrew Syntax (Winona Lake: Eisenbrauns, 1990) §36.2.1d, p. 602.

40 So Gordis, 354; cf. Ogden, 211. 


\section{The conclusion to the matter}

Although there is some variation in the precise understanding of the opening words of verse 13 , it is clear that the epilogist uses them to mark the end of his comments on the words of the sages (including Qohelet). The referent for הָכ i is most likely the words of Qohelet together with the epilogist's comments on Qohelet and the words of the sages in general - that is, everything which has preceded these words. The epilogist now offers his conclusion, which constitutes the remainder of verse 13 together with all of verse 14 .

There is little doubt as to the meaning of the epilogist's words here-he commends the fear of God and obedience to his commandments in the face of the prospect of God's judgment. What is not clear, however, is precisely how this conclusion relates to either Qohelet's words or the words of the epilogist to this point. A number of scholars argue that the epilogist herein presents a summary of the message we ought to be able to derive from Qohelet's words, that he distils Qohelet's message into one tidy saying. ${ }^{41}$ Such an argument faces significant difficulties, for it is certainly not clear how Qohelet's message can be interpreted in such a way that the epilogist derives this conclusion from them.

The greatest obstacle to this argument lies in the fact that the epilogist here assumes that God has revealed his will in his commandments-presumably the Torah. Qohelet has nowhere revealed any awareness of such commandments. ${ }^{42}$ Qohelet has been consistently depicted as operating without any awareness of any form of self-disclosure by God-were he aware of such commandments, and were his aim to commend observance of them, his failure to make reference to them previously is inexplicable. Furthermore, Qohelet's own conclusion has been stated repeatedly, and particularly in 12:8-

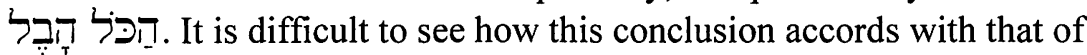
the epilogue.

The exegesis outlined above offers a more consistent understanding of the nature of this conclusion. Having presented a sample of Qohelet's words, the epilogist explains that Qohelet is pre-eminent amongst the sages and always speaks the truth. If Qohelet's words are

41 This is the argument made by both the positions I examined near the beginning of this article. See also K.A. Farmer, Proverbs \& Ecclesiastes: Who Knows What Is Good? (International Theological Commentary; Grand Rapids: Eerdmans, 1991), 196-97.

42 Murphy, 126, states that 'The epilogue is obviously putting forth an ideal which has been developed elsewhere and which is not a concern in Ecclesiastes.' 
disturbing or unusual, it is because he has spoken honestly where other sages preferred to employ pleasing words and compromise the truth. Qohelet's words reveal the inability of the wisdom movement to address even the most fundamental questions considered by the sages. The epilogist has used Qohelet's words in the same way some politicians will 'leak' confidential documents to the media in an attempt to discredit their opponents. Once the true nature of the wisdom movement has been revealed, as it is by Qohelet's words, the movement is discredited - the epilogist need only offer the briefest warnings to drive the point home, for Qohelet's words themselves do more for the epilogist's cause than any extensive critique offered by an outsider could have.

In the light of the futility of the sages' task demonstrated by Qohelet, the epilogist offers two warnings. First, since the wisdom of the sages has been clearly shown to lead nowhere, that wisdom can be largely reduced to manipulative words. Second, do not get caught up in the futile activities of the sages. Having demonstrated that the task of the sages is futile and dangerous, the epilogist points us back to the roots of wisdom - the commands of God, as Moses had already explained to the people of Israel in Deuteronomy 4:5-6:

See, just as the LORD my God has charged me, I now teach you statutes and ordinances for you to observe in the land that you are about to enter and occupy. You must observe them diligently, for this will show your wisdom and discernment to the peoples, who, when they hear all these statutes, will say, 'Surely this great nation is a wise and discerning people!' [NRSV]

Some might object to this conclusion on the basis that the Old Testament clearly contains examples of wisdom literature which do not legitimately fall under the criticisms I have argued are present in the book of Ecclesiastes. This is, to some extent, a valid objection. However, it is likely that the epilogist is not attacking all wisdom in his presentation of Qohelet's words and subsequent commentary upon them, but only a wisdom movement which, in the epilogist's time, had gone astray. Furthermore, it may well be that the radical and unorthodox wisdom movement of the epilogist's time was reformedperhaps in part through the efforts of the book of Ecclesiastes-for by the time of Sirach we find a wisdom movement whose thinking was far more closely influenced by its understanding of the Law. 


\section{Ecclesiastes and the end of wisdom}

One of the best known wisdom sayings in the Old Testament is 'The fear of the LORD is the beginning of wisdom' from Proverbs 9:10. In the light of this statement it is interesting to find the epilogue of Ecclesiastes declaring that the 'end' of the matter is 'fear God and keep his commandments'. There is, in a sense, some form of closure here with the fear of the LORD being both the beginning and end of wisdom. The Old Testament, however, does not seem to care too much for the contribution of the sages in between.

It should not be surprising that Ecclesiastes turns out to be critical of the wisdom movement. Wisdom in general receives fairly bad press throughout the Old Testament. The first time we explicitly meet wisdom is in Genesis 3, where it stands to be gained from eating the fruit of the tree of knowledge of good and evil. In Genesis 41 we meet the sages of Egypt who are upstaged by Joseph. In the book of Exodus, Pharaoh and his sages stand against Moses and Yahweh. Eventually we come to Solomon, who reached the greatest heights but also fell further than anyone in the history of Israel. Even his great wisdom could not save him.

The prophets also tend to be critical of the 'wise'. This can be seen clearly in the words of Jeremiah:

How can you say, 'We are wise, and the law of the LORD is with us', when, in fact, the false pen of the scribes has made it into a lie? The wise shall be put to shame, they shall be dismayed and taken; since they have rejected the word of the LORD, what wisdom is in them? ${ }^{43}$

Finally, it is worth noting that amongst the literature in the Old Testament which is generally categorised under the wisdom genre, wisdom does not fare too well either. Job, after all, demonstrates the utter failure of human wisdom-as presented by Job's friends- to account for Job's suffering. The book of Job eloquently makes the point that there is some knowledge to which God alone has access. And then we have Ecclesiastes, in which the epilogist offers the words of Qohelet as an extended example of the failure of the wisdom movement, and makes that the basis for a call back to obedience to the commandments of God.

In essence, Qohelet is the epilogist's 'straw man'. But the epilogist does not go to great lengths to knock down the straw man, for-to employ a different illustration-the epilogist has given Qohelet

43 Je. 8:8-9, NRSV. See also Is. $29: 14 ; 44: 25 ;$ Je. 10:7-8; $18: 18$. 
sufficient rope, and he has hung himself. To the reader familiar with the remainder of the Old Testament, it is clear that the wisdom of Qohelet has gone astray-much as Solomon himself had gone astray-and is ultimately incompatible with the message of the remainder of the canon. The book of Ecclesiastes does function to show the bankruptcy of life lived without faith in God, but it also shows the bankruptcy of a wisdom movement which had sought its own answers and had failed to find them. 